\title{
The Play of Breath: Chaucer's Narratives of Feeling
}

\section{Corinne Saunders}

\begin{abstract}
This essay explores the treatment of breath and breathlessness in the imaginative fiction of Geoffrey Chaucer. Chaucer draws on medieval medical theories, rooted in classical thought, to portray the ways that motions of the vital spirit-closely connected with breathcreate powerful physical responses, which at their most extreme cause sighs and swoons. According to this pre-Cartesian world view, mind, body and affect are intimately connected. The movement of breath plays a key role in Chaucer's depiction of the experiences of emotion, particularly love and grief, and in his treatment of gender. This physiological emphasis creates narratives of feeling that are deeply embodied. The essay focuses on Chaucer's romance writing, in particular, The Book of the Duchess, Troilus and Criseyde and The Legend of Good Women.
\end{abstract}

Keywords Breath - Swoon - Sigh - Vital spirits - Affect • Emotion • Body

I am as confident as I am of anything that, in myself, the stream of thinking (which I recognize emphatically as a phenomenon) is only a careless name for what, when scrutinized, reveals itself to consist chiefly of the stream of my breathing. (William James, "Does Consciousness Exist?") ${ }^{1}$

(C) The Author(s) 2019

A. Rose et al., Reading Breath in Literature, Palgrave Studies in Literature, Science and Medicine, https://doi.org/10.1007/978-3-319-99948-7_2 
For William James, breath, "ever the original of spirit", is "the essence out of which philosophers have constructed the entity known to them as consciousness." 2 The coincidence of breath with embodied experience, thought, feeling and consciousness is nowhere more evident than in medieval writing. Breath is a flashpoint, a culturally complex term linked both to ideas of health and life and to their converse, illness and death. It is also essential to medieval physiological models where mind, body and affect are understood to be profoundly connected. While the conventions of extreme emotion typical of medieval romance writing seem far distant from reality, the world of lovesickness, swoons and sighs taps into medieval understandings of breathing, feeling and being in the world in ways that are surprisingly realist. ${ }^{3}$ Breathing and consciousness are inextricable, and breathlessness is directly connected with disruptions of thought and feeling.

Medieval medical theory depended on the humoural theory developed by the Greek physician Hippocrates (c. 460-c. 370 BC) and refined by Galen (129-c. $216 \mathrm{AD})$ : both physical and mental health required the balance of the four humours, and medieval medicine was oriented towards restoring this balance. ${ }^{4}$ In contrast to post-Cartesian mind-body dualism, humoural theory necessitated the idea of a mind-body continuum. Ideas of mind and body were complicated by shifting theories of the soul, mental faculties and emotions. For Aristotle, while rational, intellective being was a quality of the soul, senses and cognitive faculties were situated in the heart; the idea of the heart as site of both understanding and feeling persisted in popular and literary culture through the Renaissance and beyond. According to this model, breathing was understood to be governed by the heart, the source of heat that caused the blood to pulse and flow and dilated the lungs, which drew in air; breath performed the essential role of cooling the heart through the bellows-like action of the lungs. Alexandrian medicine complicated Aristotle's theories both through a new emphasis on the brain as cognitive and sensory centre, and through theories of the "spirits" elaborated by Galen, which were central to Arabic medicine and dominated medical thought across the Middle Ages. According to Galen's theory, "pneuma (air), the life breath of the cosmos," was drawn into the body and transformed within the three primary organs into three kinds. ${ }^{5}$ The "natural spirits" created in the liver were carried through the veins and governed generation, growth, nutrition and digestion. The "vital spirits" created in the heart 
through the mixture of air and blood were carried through the arteries and heated and animated the body, governing breathing. These vital spirits were transformed in the brain into "animal spirits," carried through the nerves and controlling sensation, movement and thought, fuelling the workings of the brain. ${ }^{6}$ The lungs continued to play a central role in this model: as well as cooling the heart they provided the air that would be transformed, mixed with blood, to the vital spirits. The classical model of the lungs is explicated by Isidore of Seville (c. 560-636) in his influential Etymologies: "pulmo," the lung, is so named in Greek

because it is a fan (flabellum) for the heart, in which the pneuma, that is, the breath, resides, through which the lungs are both put in motion and kept in motion - from this also the lungs are so named. ... The lungs are the engine of the body. ${ }^{7}$

Isidore's Etymologies, widely circulated throughout the Middle Ages, contributed to the stability of classical models.

The twelfth century saw a "Renaissance" of learning, the result of the translatio studii, the movement of texts from East to West, partly through access to classical and Arabic works brought by the Muslim expansion into Europe. Galenic physiology was disseminated to the Christian West via Latin translations of Arabic and Greek medical texts in the early twelfth century, in particular the works of Constantine of Africa (d. before 1098/99). Constantine's Pantegni theorica, which translated parts of the tenth-century Arabic medical encyclopaedia of "Haly Abbas" (Ali ibn al-'Abbas al-Majusi), itself based on Galenic works, along with a translation of the treatise on the Galenic theory of humours and spirits by the ninth-century scholar and physician "Johannitius" (Hunayn ibn Ishaq), Isagoge Johanitii in Tegni Galeni, became foundation texts for the Articella or Ars medicine, the collection of six medical works which formed the basis of Western medical theory and entered the university curriculum in the thirteenth century. ${ }^{8}$ The medical theorist Bartholomaeus Anglicus, whose De proprietatibus rerum (On the Properties of Things, c. 1240) was translated into English by the natural philosopher John of Trevisa (c. 1399), elaborates in detail the theory of the spirits, drawing directly on Constantine. He sets out the processes of breathing and the workings of the vital spirits or "virtue of life" with careful attention to physiology: 
Aftir pe vertu of kynde folewip pe vertu of lif pat 3euep lif to pe body and hap place in pe herte. Out of pe herte comep lif to al pe limes. ... Pis vertu of lif openip pe herte by worchinge of pe longen and drawep in aier to the hert and sendip forp from pe herte to opir limes by smale weyes. And by help of pe vertu pat closith and riuep [pierces] and openith pe herte pis vertu worchip and makep brepinge in a beest. And by brepinge pe brest meuep continualliche, but sinewis and brawnes bep first imeued. Pis blast, brep, and onde [breath/spirit] is nedeful to slake pe kindeliche hete, and to foode of pe spirit of lif, and also to pe gendringe of pe spirit pat hatte animalis pat 3euep felinge and meuynge. Pe kepinge of pe kinde hete is a temperat indrawinge of coold aier and pe kepinge of pe spirit pat hatte spiritus vitalis "of lif". Of pe temperament of pis spirit is pe spirit gendrid pat hatte animalis pat 3euep felinge. Perfore noping is more nedeful to kepe and to saue pe lif pan brep, wel disposid and ordeyned in alle pointis. All pis seip Constantinus in Pantegni. ${ }^{9}$

The role of breath is twofold: it cools the heart and generates the vital spirits, which are required to create the animal spirits. The model clearly signals the interdependence of mind and body, all fuelled by the breath.

It is easy to see how readily classical concepts of the pneuma, the life breath of the cosmos, transferred to Christian conceptions of the Holy Spirit, and to the Hebrew notion of ruach, the breath of God. The concept of pneuma is repeatedly employed in the New Testament, in particular by St. Paul, who takes up both classical and Old Testament notions. The Spirit of divinity and life is external to the individual, moving within the cosmos; but it is also inspiring and inspired, moving the souls of men and breathing new life - the life of the Spirit-into them. Christian conceptions of the soul, however, required distinctions between air and soul not made in classical theories of pneuma as world soul. Isidore of Seville is emphatic concerning the difference between soul-anima, spiritus - from the air breathed in through the mouth:

... we seem to stay alive by drawing air into the mouth. But this is quite clearly untrue, since the soul is generated much earlier than air can be taken into the mouth, because it is already alive in the mother's womb. ${ }^{10}$

Different theories competed across the Middle Ages. The pneuma was most typically viewed within a physiological framework as "the instrument of the soul" but could, in its "animal" form in the brain, also be 
understood as the corporeal aspect of a tripartite soul. ${ }^{11}$ There is always some slippage between the idea of pneuma - the breath of God breathing life into man-and pneuma/spiritus, the breath. The concept of the "vital spirits" inevitably overlaps with that of the Holy Spirit, giving breath a special status as the animating force. Spirits are often written in the singular, heightening the overlap. The heat associated with the heart also created a physiological context for the prevalent imagery of fire frequently associated with the Holy Spirit, which descends in tongues of fire at Pentecost. Richard Rolle, for example, takes up this idea in his Incendium Amoris (The Fire of Love): the work opens with Rolle's memorable description of the physical sensation of the flame of divine love, so strong that he touches his breast to see whether his heart is literally on fire: "I cannot tell you how surprised I was the first time I felt my heart begin to warm. It was real warmth too, not imaginary, and it felt as if it were actually on fire." 12 The divine pneuma is understood as both air and fire, corresponding readily to physiological concepts of pneuma as breath and the vital spark of life.

The play of breath in all these senses underpins medieval theories of the emotions, to which the concept of the mind-body continuum was also essential. Such ideas resonate strikingly with the view of William James, radically anti-Cartesian in its time, of emotion as rooted in affect ("the feeling of the same changes as they occur IS the emotion,") with Merleau-Ponty's conception of embodiment, and with neuroscientific theories of affect and the role of emotion in cognition such as those of Antonio Damasio. ${ }^{13}$ Medieval models understood emotions to occur through the movements of the vital spirits and natural heat produced in the heart and travelling through the arteries. They could be caused by direct sensory experience or by imagination and memory, but always had both physical and mental consequences. In extreme pleasure or anger, the vital spirits and accompanying heat moved out of the heart to other parts of the body: the heat might be visible in blushing, frenzy or manic movement. In extreme grief, distress or fear, or through a sudden shock, by contrast, the vital spirits and heat withdrew from the arteries into the heart. Such withdrawal of spirits was synonymous with withdrawal of breath and might cause unconsciousness or even death. Swoons, in particular, signal great grief, distress, terror or ecstasy. Sighs, intimately connected with emotional experience, also play a vital role as a means to purge and cool the overburdened or overheated heart. As Naya Tsentourou demonstrates in this volume in relation to Hamlet, sighs also 
came to be seen as dangerous: too many might cause the heart to dry out and wither. Etymology signals the close connection between sighs and swoons in the medieval period. The Middle English terms for sigh ("swough," also meaning a forceful motion or impetus, deriving from Old English "swōgan," to resound, sound, rush or roar) and swoon ("swoun," deriving from Old English "geswogen," in a faint/overcome, also ultimately from "-swōgan" ["āswōgan," to overcome]) are closely related, and may be spelt identically. ${ }^{14}$ The sense of sudden motion and overwhelming force suggests the powerful affective movement of the spirits and its profound effects on body and breath. ${ }^{15}$

The writings of Geoffrey Chaucer engage in particularly striking detail with such conceptions of breath and vital spirits. Chaucer, like his contemporary John Gower, was both interested and well versed in natural philosophy and medicine. He was familiar with Bartholomaeus Anglicus' treatise, perhaps through John of Trevisa's translation, as well as with a range of other medical, philosophical and theological works. The play of breath in Chaucer's writing opens onto the exploration of mind, body and emotion, individual psychology and agency, and the power of affect. The interplay of thinking, feeling and breathing at moments of extreme emotion, positive and negative, is particularly revealing. Swoons and sighs are not simply conventional indicators of feeling but markers of profound, often formative affect that construct individual psychology. It is narratives that participate in the structures and emphases of romance, the imaginative fiction of the period, that engage most acutely with such emotional extremes, which are typically associated with the individual experience of love, its affects and its losses.

It is often an emphasis on the physicality of experience that takes Chaucer's depictions of emotion beyond convention. In Venus's temple in the Parliament of Fowls, the narrator sees painted on the walls stories of tragic love and hears the sound of "sykes [sighs] hoote as fyr"; "Whiche sikes were engendered with desyr, / That maden every auter for to brenne / Of newe flaume..."16: they are all caused by jealousy. Similarly, in the Knight's Tale, the walls of the Temple of Venus depict "[t]he broken slepes, and the sikes colde, / The sacred teeris and the waymentynge [lamenting], / The firy strokes of the desirynge" (192022). Love is a highly physical phenomenon, a sickness. The topos finds its origins in classical poetry, particularly that of Ovid, but is much developed and heightened by medieval poets; medical writings of the period recognised lovesickness as a serious illness. ${ }^{17}$ The thirteenth-century 
Le Roman de la Rose begun by Guillaume de Lorris (c. 1237) and completed by Jean de Meun (c. 1275), and partly translated into English by Chaucer, offers the archetypal model of the lover wounded by the arrow shot by the God of Love. ${ }^{18}$ With the shaft left in his heart, the narrator manifests the symptoms of lovesickness, changing colour, fainting and sighing in pain: "I anoon gan chaungen hewe / For grevaunce of my wounde newe, / That I agayn fell in swonyng / And sighede sore in compleynyng" (1865-68). The narrative of the Roman de la Rose suggests the physiology of the experience: the heart is literally wounded, and the effect of extreme affect on the vital spirits is manifest in the lover's loss of consciousness; his sighs breathe out the excessive heat of the spirits that overload the heart. The lover marvels to the God of Love at his own suffering, depicted with vivid physicality: "How ony man may lyve or laste / In such peyne and such brennyng, / In sorwe and thought and such sighing, / Ay unrelesed woo to make" (2726-29). Chaucer uses the idea to comic effect in his Miller's Tale, when the soon-to-be cuckolded husband John adopts the behaviour of a courtly lover in wooing his wife Alisoun, "[h] e siketh with ful many a sory swogh" (3619); the clerk Absolon follows suit. Proto-courtly behaviour and refined emotion contrast humorously with the frank sexuality of the tale: the sufferings of lovers are swiftly replaced by fulfilment or bawdy denial of desire. Chaucer's romances, by contrast, probe through the play of breath the painful extremes of emotional experience, the ways in which such affect shapes the psyche, and hence, the embodied quality of being.

Chaucer's earliest narrative poem, the dream vision The Book of the Duchess (1369-72), explores in acutely physiological terms the experiences of grief and loss, and the profound affects on heart and mind. ${ }^{19}$ Underlying its narrative is the event it in some sense commemorates, the death of John of Gaunt's wife Blanche, Duchess of Lancaster in $1368 / 69$. The poem concerns both physical and metaphorical "herthuntyng" (1313) - not only the hart hunted by the emperor Octavien in the narrator's dream, but also the grief-stricken hearts of the narrator, of the classical heroine Alcyone, whose story the narrator reads to combat his insomnia, and of the Man in Black, the dream-figure whose loss echoes and surpasses the narrator's own melancholy. The frame of the dream is coloured by repeated references to the movements of breath and vital spirits in and out of the heart. The melancholy humour is depicted in terms of physical cooling: the withdrawal of the vital spirits into the heart has "sleyn [the narrator's] spirit of quyknesse" (26)—a sickness from 
which only one physician, his lady, can heal him. The inset story describes Alcyone's distress at the news of her husband Ceyx's death, which causes a movement of the spirits so violent that she swoons through withdrawal of breath: she is "as cold as ston" (123). The cold, heavy dullness of grief is further mirrored in Alcyone's "dede slep" (127), the description of Ceyx's corpse, "pale and nothyng rody" (143), the sleep of the gods in their dark, infernal cave and even the "dedly slepynge soun [sound]" (162) of water in the underworld. Finally, the narrator, who seems half asleep, a "mased thyng" (12) engrossed in his fantasies, himself falls asleep. The clustering images of sleep, death, melancholy, sorrow, heaviness and bewilderment creates something of the muted, melancholy atmosphere of Keats's Ode on Melancholy, "For shade to shade will come too drowsily, / And drown the wakeful anguish of the soul." 20

In the dream-narrative of the Man in Black's loss, Chaucer offers remarkable physiological detail, much developed from his sources. The great physicians of history are evoked: "[n]oght Ypocras ne Galyen [Hippocrates or Galen]" (572) can treat the knight's sorrowful heart. The heart is depicted as fainting in grief, causing the spirits to withdraw:

His sorwful hert gan faste faynte

And his spirites wexen* dede; *became

The blood was fled for pure drede

Doun to his herte, to make hym warm -

For wel hyt feled the herte had harm. (488-92)

As vital spirits and blood move into the heart, the "membre principal" (495) of the body, colour and life are withdrawn: "al / Hys hewe chaunge and wexe grene / And pale, for ther noo blood ys sene / In no maner lym [limb] of hys" (496-99). His sorrows "lay so colde upon hys herte" that he wonders how he can live, and the withdrawal of vital spirits in turn deprives his brain of animal spirits so that his thought too is "hevy" $(508,509)$. Chaucer takes up and much extends the description in Machaut's Jugement dou Roy de Behaingne (c. 1340), one of his sources for the poem, of its grieving lady's heavy heartache, pallour and pensiveness. The Man in Black becomes the epitome of grief: " $y$ am sorwe, and sorwe ys y" (597). His black attire, abstraction and melancholy might seem to render him an antecedent of Hamlet, though the cause of his grief is very different. In the Man in Black's long lament and account of the loss of his lady, the imagery of heartsickness and death 
recurs, contrasting with remembered health and happiness in courtship and marriage. In his final revelation of his lady's death, the affects of the loss of vital spirits are figured at their most extreme: "he wax as ded as stoon" (1300). With this, the "hert-huntyng" and dream are at an end, but there is no consolation: rather, death is memorialised in the poem, as the frozen affects of grief become art. The swooning figure of the Man in Black is transformed into the memorial poem, a complement to the marble effigy of his dead duchess commissioned by John of Gaunt.

The extended epic romance that begins the Canterbury Tales, the Knight's Tale (1386-88), again takes up the conventions of lovesickness, infusing them with physiological realism. In his depiction of the affects of love on the minds and bodies of the two cousins, Palamon and Arcite, who on seeing the lady Emilye walking in a Maytime garden suddenly fall in love with her, Chaucer interweaves with contemporary medical theory the ancient neo-Platonic conception of love as striking through the eyes to wound the heart. Palamon looks at Emilye, "And therwithal he bleynte and cride, 'A!' / As though he stongen were unto the herte" (1078-79). The heart is directly affected: the withdrawal of the vital spirits - blood and breath-into the heart signalled through the pain and pallour. Arcite's feeling is articulated in similar terms of mortal illness and echoed in the sighs that breathe out his burden: he "is hurt as muche as he, or moore. / And with a sigh he seyde pitously, / 'The fresshe beautee sleeth me sodeynly / Of hire that rometh in the yonder place; / And but I have hir mercy and hir grace, / That I may seen hire atte leeste weye, / I nam but deed; there nis namoore to seye" (111622). Jealousy only heightens the extreme affects of withdrawal of vital spirits, seizing Palamon "by the herte / So woodly [madly] that he lyk was to biholde [to look upon was like] / The boxtree or the asshen dede and colde" (1300-2). The depiction of the deathly affects of love combines convention and realism. Chaucer elaborates on Arcite's malady by placing it as both mental and physical, using contemporaneous theories of the brain:

... lene he wex ${ }^{*}$ and drye as is a shaft; * *he became lean *stick

His eyen holwe* and grisly to biholde, * ${ }^{*}$ sunken

His hewe falow* and pale as asshen colde, *sickly yellow

...

So feble eek were his spiritz, and so lowe, And chaunged so, that no man koude knowe 
His speche nor his voys, though men it herde.

And in his geere* for al the world he ferde* *demeanour *behaved

Nat oonly lik the loveris maladye

Of Hereos*, but rather lyk manye, * *love-sickness * mania

Engenderd of humour malencolik

Biforen, in his celle fantastik. ${ }^{*}(1362-76) \quad$ *imagination

The passage addresses the affects of love on the animal spirits, into which the vital spirits are transformed in the brain. Chaucer may have drawn on Bartholomaeus Anglicus's description of how the melancholy humour works on the "celle fantastik," the ventricle of the brain controlling the imagination, to impair judgement and reason. ${ }^{21}$ Whereas in grief the Man in Black's vital spirits withdraw into the heart, in extreme desire heat from the heart, and the accompanying vital spirits, are drawn in by the overactive brain, making the eyes appear hollow and the face pale. The resulting excess of animal spirits causes Arcite's inner senses to return again and again to the image of his beloved, bodying it forth repeatedly in his mind's eye in a kind of "manye" (1374), mania or frenzy. Looking in a mirror, he realises the dramatic effect on his own appearance: "[he] saugh that chaunged was al his colour, / And saugh his visage al in another kynde" (1400-1); he is able to return to Athens without being recognised. The movement of breath is as essential to the extremes of desire as it is to those of grief, causing the movement of the vital spirits into the brain, and the frenzied work of the animal spirits into which they are transformed. In a different way, the normal workings of the vital spirits are impaired: as when they are withdrawn into the heart, their excessive movement into the brain destroys physical health, emaciating and weakening the body and removing its colour and animation. Physical and mental, body and brain, are intimately connected, necessitating an understanding of emotional experience as deeply embodied and situated in the play of breath.

The end of the tale returns more explicitly to the issue of the vital spirits and breath in Chaucer's remarkably extensive account of the injury sustained by Arcite when, having won Emilye's hand in the grand tournament orchestrated by Theseus, he is thrown from his horse at the command of the god Saturn. The detail is notable for its physiological realism: pierced by his saddle bow, Arcite's breast swells, causing increasing pain in his heart because the clotted blood cannot be expelled and "[c] orrupteth" (decays, 2746). The poisonous matter presses on and 
causes to swell "[t]he pipes [tubes] of his longes"; all the muscles in his breast are "shent [destroyed] with venym and corrupcioun [decayed matter]" (2752-54). The spirits are prevented from their natural work: the poison cannot be expelled by the "vertu expulsif, or animal, / Fro thilke vertu cleped natural" (2749-50). The expulsive or "offeputtinge" property ("vertu") is envisaged in medical theory as a function of the natural spirits originating in the liver, ridding the body of waste: "pat puttip of what is greuous and no3t accordinge"; this function is governed by the animal spirit, which "meuep alle pe limes." 22 Because Arcite's movement is inhibited, the expulsion of poison cannot happen, and at the same time, the vital spirits animating the body are prevented from moving out from the heart to the lungs and arteries, while breathing cannot serve its natural function of cooling the heart. As "vital strengthe" (2802) withdraws, the "coold of deeth" falls upon Arcite's body (2800), leaving only the rational soul. Here Chaucer turns to the ancient model of thought and feeling as situated within the heart to convey rational being: "Oonly the intellect, withouten moore, / That dwelled in his herte syk and soore, / Gan faillen whan the herte felte deeth. / Dusked [grew dark] his eyen two and failled breeth" (2803-6). Chaucer employs extensive medical detail to create a powerful impression of the effects of a wound that prevents natural functioning of the body, and hence, the gradual failure of the spirits and the dying out of the intellect itself. Breathing and the vital spirits animate body and mind, and the intimate, physical connections between heart, spirits, breath, intellect and soul are crucial to Chaucer's realisation of being in the world.

Chaucer's epic romance Troilus and Criseyde (c. 1382-85) explores the complex intersections of mind, body and affect at the greatest length, in the narrative of the sorrows of Troilus, first falling in love with and then betrayed by his lady Criseyde. The play of breath as the vital spirits move in and out of the heart marks the process of love on Troilus' body in his sighs, tears, swoons and finally, his wasting away on grief. Love is painful and invasive, a punishment inflicted by the God of Love on Troilus for his laughter at the folly of lovers, and an affliction of both body and mind. Like The Knight's Tale, the narrative relies on the neo-Platonic concept of the connection between eyes and heart, but is also informed by detailed physiological theory. As Troilus's gaze rests on Criseyde, he is "astoned," a verb suggesting the withdrawal of vital spirits into the heart, which is caused to "sprede and rise" as if on fire, so that 
he "softe sighed" (I, 274, 278-89). The response is both conventional and medically alert: sighs are an instinctive response to the overheated heart. The gaze quickens desire, "affeccioun" (I, 296), a term that signals the physicality of feeling, its embeddedness in the movement of the vital spirits, which are drawn out of the heart to engage the passions, felt at once in body and in mind. The account of Troilus's feeling emphasises this extreme movement: "sodeynly hym thoughte he felte dyen, / Right with hire look, the spirit in his herte" (I, 306-7). His response is sighs and groans, which release the heart (I, 360). Chaucer repeatedly employs the imagery of burning, "hote fir" (I, 445, 490), evoking the heart's overheated quality as well as conventionally signalling desire. The work is suffused with imagery of heartsickness, which afflicts the body to the extent of causing Troilus to swoon, losing breath altogether: "[Troilus] no word seyde, / But longe he ley as stylle as he ded were; / And after this with sikynge he abreyde [started up]" (I, 722-24); again, sighing functions to relieve the heart. While Pandarus speaks, Troilus seems "in frenesie" (I, 727), a term used here to suggest not frenzy of movement but abstraction bordering on unconsciousness. Later, seeing Criseyde weep, Troilus feels "[t]he crampe of deth to streyne [constrain] hym by the herte" (III, 1071) and again falls unconscious:

Therwith the sorwe so his herte shette* * ${ }^{*}$ shut
That from his eyen fil there nought a tere,
And every spirit his vigour in knette, ${ }^{*}$ *contracted its force
So they astoned* or oppressed were.
The felyng of his sorwe, or of his fere,
Or of aught elles, fled was out of towne;
And down he fel al sodeynly a-swowne. (III, 1086-92)

Feeling is acutely embodied and overwhelming, conveyed through the depiction of the closing heart, the withdrawal of spirits astounded by sudden affect, the numbing of the senses, and the resulting swoon. ${ }^{23}$ In a characteristically Chaucerian shift in tone, the medical emphasis is comically reiterated when Pandarus and Criseyde chafe Troilus's pulse and palms until breath returns.

The affects of Troilus's love, written on the body in sorrowful sighs, tears and swoons, and in the burning fire of love, are intensified in the later books. On hearing that Criseyde is to be sent to the Greek camp in exchange for the prisoner Antenor, Troilus is possessed by "furie" 
and "rage" (IV, 253) that express themselves in frenzy or "woodnesse [madness]" (IV, 238). This madness has none of the wilful verbosity of Hamlet's. The affects of the spirits rushing out from Troilus's heart are so extreme that his behaviour resembles that of a wild bull "idarted to the herte" (IV, 240); he rushes round the room, striking his breast, beating his head against the wall and the ground. The violent movement of breath outwards is reflected not only in Troilus's actions but also his roaring out of his complaint. At last the frenzy "that his herte twiste and faste threste" is replaced by grief, his tears accompanied by "[a] thousand sikes, hotter than the gleede [glowing coal]" that release the overheated heart (IV, 254, 337). Eventually, however, this results in overcooling, as too much heat is lost: "so his peynes hym torente [tore him], / And wex so mat [exhausted/dejected], that joie nor penaunce / He feleth non, but lith forth in a traunce" (IV, 34l-43). Breath has left his lungs and he becomes inanimate; Pandarus's own heart grows cold in sympathy (IV, 362). The focus on heartsickness and its affects is sustained and enhanced as Troilus waits for Criseyde to return as she has promised: his "maladie" is such that he believes he cannot live $(\mathrm{V}, 316)$; he experiences a "tremour ... aboute his herte" $(\mathrm{V}, 255)$. As her betrayal becomes apparent, physical affect is so extreme that, like Arcite's, Troilus' appearance is dramatically changed:

He so defet* was, that no manere man Unneth* hym myghte knowen ther he wente; So was he lene, and therto pale and wan, And feble, that he walketh by potente. ${ }^{*}$ (V, 1219-22)
* enfeebled

*scarcely

${ }^{*}$ crutch

Again, the heart is the focus: "He seyde his harm was al aboute his herte" (V, 1225). Chaucer medicalises and extends Boccaccio's conventional imagery of the troubled heart, depicting withdrawal of the spirits of a kind so extreme that the body is unmade. ${ }^{24}$

The physiological model of the spirits and the movement of breath, then, are critical to Chaucer's depiction of emotional experience as a deeply embodied phenomenon. One effect of this model is to identify the lover as sufferer in two senses-as suffering the pains of love, but also as suffering or acted upon by the passions, and in this sense as passive. The passivity of feeling, weeping, sighing, swooning is mitigated by an emphasis on cognition, recognition, knowing and making 
sense of emotional experience. In Chaucer's male lovers, it is also mitigated by an emphasis on prowess and chivalry: Arcite and Palamon are first encountered on the battlefield, and enact their rivalry through both their battle in the forest and the great tournament that concludes the tale; Troilus rides through the streets of Troy in triumph after battle, his chivalric excellence increases through love, and he is eventually killed on the battlefield. While we only see the Man in Black as suffering lover, he is allusively identified as John of Gaunt; the narrator's mode of address places him as feudal lord, and it is evident from his narrative that he actively fulfils this role. Action of this kind, however, is denied Chaucer's female victims of love, and it is striking that in relation to his depiction of female protagonists, Chaucer is careful to balance his depiction of the body overcome by suffering with an emphasis on agency. Breath and the movement of the spirits play essential roles in demonstrating truly felt emotion and virtue, but they are balanced by the exercise of free will and thought-through choice.

Chaucer's Man of Law's Tale exemplifies his treatment of breath in relation to female protagonists. The tale is haunted by the image of Custance's "deedly pale face" (822). Accused of murder and led through the streets, her pallour provides physical evidence of the withdrawal of the vital spirits through fear: "Have ye nat seyn somtyme a pale face ... ?" (645) Her immediate response to the murder of her host's wife is to swoon: "For verray wo hir wit was al aweye" (609). The withdrawal of vital spirits and hence of animal spirits in the brain prevents the working of "wit," the inner senses. Yet Chaucer is also careful to emphasise Custance's agency: the withdrawal of vital spirits-air and blood-is balanced by control when she is publicly accused of murder: "So stant Custance, and looketh hire aboute" (651). Exiled on the sea, she is not portrayed as a swooning victim but from the start "taketh in good entente / The wyl of Crist" (824-25). By contrast, at her reunion with her husband, affect is written on her body in the most extreme terms: "she, for sorwe, as doumb stant as a tree, / So was hir herte shet in hir distresse / Whan she remembred his unkyndenesse. / Twyes she swowned in his owene sighte" (1055-58). As with Chaucer's portrayals of male lovers, the imagery of the heart closing is physiologically acute: Custance swoons repeatedly as the spirits withdraw, her response reflected in her husband's swoons and tears. Now it is as if affect is released by the restoration of natural order and justice. In contrast, Chaucer's contemporary John Gower, who uses some of 
the same legends in his Confessio Amantis, an extended story collection exemplifying the seven deadly sins in relation to love, chooses to emphasise the movement of the spirits more consistently, particularly through the response of swooning. In Gower's extended narrative of Constance, intensely felt affect and the accompanying loss of breath are emphasised in relation to suffering: on discovering the dead Hermengyld, Constance lies "swounende ded for fere ... stille as eny Ston." 25 Gower's Constance, cast out in her rudderless ship, evokes pity precisely through the extremes of her physical response: she lies "[s]wounende as ded" (II, 1063). Feeling is physically manifest in the movement of the vital spirits and breath- the swoon and the rush of tears, which are contrasted by her prayer for her child and return to strength. Again in opposition to Chaucer's account, however, at the denouement Gower offers no detail concerning Constance's response: here his interest is in the affects of recognition and reunion experienced by the male lover, whose predicament in some sense chimes with that of his narrator and alter ego, Amans.

Chaucer's Legend of Good Women engages most extensively with the experience of tragic female love, though the tone of its series of classical legends, purportedly written to demonstrate female virtue, is notoriously ambiguous. The women of the Legend can seem troublingly passive, repeatedly written out in death, yet Chaucer's realisation of the interconnected workings of mind, body and affect also affords its subjects individuality and agency. The physiology of grief provides Chaucer with the means to explore natural feeling and virtue. Thus Thisbe's heart pounds with emotion: "like the wawes quappe gan hire herte" (865); she grows as pale as boxwood. The withdrawal of vital spirits is made visible in her pallour, swoon and tears, so that, like the Man in Black, she becomes a living emblem of grief. Whereas Aeneas's falseness is reflected in the unnatural division between body and mind, so that his countenance belies his intention, Dido manifests intense grief: as the vital spirits are sent back from the arteries into the heart, "[t]wenty tyme yswouned hath she thanne" (1342). Ariadne's heart similarly grows "cold" (2197), while Hypsipyle's grief at Jason's betrayal is the most extreme manifestation of the withdrawal of vital spirits and breath: she "deyede for his love, of sorwes smerte" (1579).

In the Legend, embodied emotion is also true, virtuous emotion, contrasting with the feigned emotion of men. Its physiological basis underwrites that truth, taking emotional experience beyond convention. Yet extreme physical affects are also, as in the Man of Law's Tale, employed 
selectively, particularly in relation to suicide, which is repeatedly depicted as a conscious choice. The play of breath at the last is consciously orchestrated. Thus Cleopatra's, Thisbe's, Phyllis' and Dido's deaths are carefully thought-through actions. Cleopatra responds to her "sorweful herte" not by swooning but by fulfilling the covenant she has made to feel the same "wel or wo" as Anthony $(681,689)$. Thisbe's "drery herte" fuels the act that proves "[a] woman dar and can as wel" as a man: "My woful hand ... / Is strong ynogh" $(810,923,890-91)$. Dido's embodiment of grief is replaced by her carefully reasoned suicide, enacted with Aeneas's sword, and allowing time for prayer and lament. Chaucer controls affective extremes to highlight free will and agency, in particular, in relation to the choice of when and how to take the last breath. Whereas Chaucer balances affect with control to suggest agency, Gower's renditions of the same legends emphasise the power of affect over rationality. Thus his Thisbe swoons on finding Piramus's body, a "traunce" (III, 1447) that embodies extreme grief: she regains her breath only to voice her final lament. Death results from the sorrow which "overgoth hire wittes" (III, 1488) - a brief evocation of the withdrawal of the spirits-in contrast to the reasoned suicide of Chaucer's Thisbe. Suicide, for Gower, is the ultimate expression of extreme grief, an act of the body bereft of reason. Though in the Confessio Dido's death is recounted only briefly, with the emphasis placed on her complaint, the enduring image is of frenzied grief, that of the swan who drives a feather into her brain for sorrow.

In Chaucer's legend of Lucrece, the movement of the vital spirits and the play of breath fulfil their most critical function, proving Lucrece's innocence in relation to her rape, a subject extensively debated by medieval theologians from Augustine onwards. ${ }^{26}$ Fear of the rapist Tarquinius paralyses Lucrece's cognitive processes through withdrawal of vital spirits and hence of animal spirits: "Hire wit is al ago" (1797). Chaucer compares her response to that of animals frozen in terror, as is the lamb in the claws of the wolf. The extreme affects of fear preclude any possibility of collusion by causing the complete withdrawal of the vital spirits into the heart: "what for fer of sclaunder and drede of deth, / She loste bothe at ones wit and breth ... . / She feleth no thyng, neyther foul ne fayr" (1814-18). Critical views placing Lucrece's swoon as symbolic of the failure of agency do not take account of medieval models of the physiology of emotion, the affective movement that leaves the body without "wit and breth." Chaucer's phrasing underlines the swoon's origin in the constraint of vital spirits and accompanying loss of breath. 
Paradoxically, passivity is rooted in the extreme action of the spirits, and proves steadfastness and "trouthe" (1860). Lucrece's swoon contrasts physically with the rushing out of Tarquinius's overheated vital spirits from his fiery heart (1751), which leads him to enact his desire. Lucrece's suicide, by contrast, is a deeply reasoned action, described through strikingly active language: "she rafte hirself hir lyf" (1855). Chaucer's final emphasis is on her conscious steadfastness of mind, manifest in her fixed will: "Ne in hir wille she chaunged for no newe" (1875). The moment that breath is lost in self-inflicted death also proves "the stable herte, sadde and kynde" (1876). Gower adopts the same defence in relating the story of Lucrece. In his narrative, the withdrawal of spirits to the heart is an expression of femininity: she "thurgh tendresce of wommanhiede / Hire vois hath lost for pure drede" (VII, 4975-76). Like Chaucer's Lucrece, she is redeemed from any accusation of guilt: she "swounede" and "lay ded oppressed" (VII, 4986-87); Gower's physiological detail, however, is notably less, and he does not explore the rational, volitional aspects of suicide.

Chaucer's Legend of Good Women concludes with legend of Hypermnestra, whose femininity is defined by her inability to take up male weapons and commit murder. Chaucer memorably evokes the withdrawal of vital spirits: "As cold as any frost now waxeth she; / For pite by the herte hire streyneth so" (2683-84); she weeps and shakes, swooning three times. Regaining consciousness, she recognises violence as antithetical to her gender: "I am a mayde, and, as by my nature, / And bi my semblaunt and by my vesture, / Myne handes ben nat shapen for a knyf" (2690-92). The tale is incomplete, breaking off with Hypermnestra's imprisonment, and Chaucer emphasises her vulnerability: "This sely woman is so weik - Allas! / And helples" (2713-14). Yet if she is the archetypal female victim, it is also striking that precisely the extremes of affect reflected in loss of breath and in the swoon bring her to the realisation of her nature and the defence of trouthe. In her seeming passivity and refusal to act, Hypermnestra also exercises agency and free will. The movement of breath causing unconsciousness inspires conscious choice and assertion of the will.

Engagement with the play of breath, the precise physiology of the vital spirits that governs the emotions and the power of affect over body and mind, then, allows Chaucer to dramatise the physicality of intense experience and the embodied quality of emotion, to probe the intersections of virtue and feeling, to explore questions of agency and 
to illuminate the intimate connections between mind, body and affect. Romance structures and their conventions have their own spiritual force: they work to evoke and to animate the textures of human experience, of thinking, feeling and breathing in the world.

\section{Notes}

1. James $(1912,36-37)$.

2. Ibid., 37.

3. This essay draws on research undertaken for the "Life of Breath" (http:// www.lifeofbreath.org/) project, generously funded by a Wellcome Trust Senior Investigator Award (WT098455MA). It is also indebted to research undertaken for "Hearing the Voice" (http://hearingthevoice. org/), funded by a Wellcome Trust Strategic Award (WT086049) and Collaborative Award (WT108720). I am very grateful to the Trust for their support of my research and to my colleagues for their insights. See also my essay "Mind, Breath and Voice in Chaucer's Romance Writing", in Hilger, ed. (2017, 119-141). I am grateful to the editor for permission to draw on this material here.

4. On medieval medicine, see further Cameron (1993), Getz (1998), Rawcliffe (1995), Rubin (1974), Siraisi (1990) and Talbot (1967).

5. Porter $(1997,77)$. For an extensive study of theories of pneuma in classical philosophy and medicine, and in early Christian thought, see Verbeke (1945), and further on classical thought, van der Eijk (2005, 119-135).

6. Ibid., 76-77. On medieval theories of the brain, see Harvey (1975) and Avicenna (1968).

7. Isidore of Seville (2006, XI.i.124).

8. Further on Constantine's Pantegni, see Burnett and Jacquart, ed. (1994).

9. Bartholomaeus Anglicus, trans. Trevisa (1975, III.15, vol. 1, 104-105); for the Latin, see Bartholomaeus Anglicus (1979, 35-36).

10. Isidore of Seville (2006, XI.1.7).

11. Grudzen $(2007,63-64,200-201)$.

12. Richard Rolle $(1972,45)$; for the original see Rolle $(1915,145)$.

13. James $(1884,189-190)$, and see Damasio $(2000,2006)$. On theories of the emotions in classical and medieval philosophy, see Knuuttila (2004) and Pickavé and Shapiro, ed. (2012).

14. See Oxford English Dictionary, sigh, $n$. 1, sigh v. 1a., 2a., 3b.; swoon, n., la., lb; swoon v., la, 2; Middle English Dictionary, swǒugh, n., 1, 2.

15. On the swoon as caused by "strong emotional disturbance" affecting the spirits and by sexual deprivation, see Weiss $(2011,133)$; on literary swoons see Windeatt (2011).

16. Parliament of Fowls, in Chaucer (1987, lines 246-250). All subsequent references to Chaucer's works are to this edition, cited by line number. 
17. On medical writings on lovesickness from Constantine's Viaticum onwards, see Wack (1990).

18. Chaucer's Prologue to The Legend of Good Women refers to his translation of the Roman de la Rose. Three fragments of a Middle English Romaunt of the Rose survive, attributed to Chaucer in Thynne's sixteenth-century edition; of these only Fragment A (cited here and perhaps written early in his career) is now thought to be Chaucer's, though critical debate continues.

19. On the psychological physiology of the heart and reception of these ideas in England from the twelfth century onwards, see Metlitzki (2005, 64-73).

20. Keats $(1970,539$, lines 9-10).

21. See Bartholomaeus Anglicus, trans. Trevisa (1975, VII.6, vol. 1, 350): the passage instances "grete pou3tes of sorwe, and of to greet studie, and of drede," but not love; for the Latin see Bartholomaeus Anglicus (1964, VII.6).

22. See Bartholomaeus Anglicus, trans. Trevisa (1975, III.8, III.12, vol. 1, 97, 99); for the Latin see Bartholomaeus Anglicus (1979, 28, 30). On this passage, see Chaucer (1987, Knight's Tale 2749), explanatory note; and further Aiken (1936) and Curry (1960, 139-145).

23. On Troilus as swooning "in part because of an as-yet unfulfilled sexual life," rather than simply through heightened emotional sensitivity, see Weiss $(2011,133)$.

24. For a parallel text presenting Boccaccio's Il Filostrato alongside Chaucer's Troilus and Criseyde, see Chaucer (1984).

25. Gower (1990, 1991, II, 846-847). All subsequent references to the Confessio Amantis will be to this edition, cited by book and line number.

26. See further Saunders (2001, 152-177, 267-273).

\section{REFERENCES}

Aiken, Pauline. 1936. Arcite's Illness and Vincent of Beauvais. PMLA 51: 361-369.

Avicenna. 1968. Liber de anima seu Sextus de naturalibus, ed. Simone van Riet. Leiden: Brill.

Bartholomaeus Anglicus. 1964 [1601]. De rerum proprietatibus. Frankfurt: Minerva.

Bartholomaeus Anglicus. 1975. On the Properties of Things: John of Trevisa's Translation of Bartholomaeus Anglicus De Proprietatibus Rerum, vol. 3, ed. M.C. Seymour. Oxford: Oxford University Press.

Bartholomaeus Anglicus. 1979. On the Properties of Soul and Body. De Proprietatibus Rerum Libri III et IV, ed. R. James Long. Toronto Medieval Latin Texts. Toronto: Centre for Medieval Studies and Pontifical Institute of Mediaeval Studies. 
Burnett, Charles, and Danielle Jacquart (eds.). 1994. Constantine the African and 'Al̄ Ibn Al-'Abbās Al-Mă̌̀usī: The "Pantegni" and Related Texts. Studies in Ancient Medicine 10. Leiden: Brill.

Cameron, M.L. 1993. Anglo-Saxon Medicine. Cambridge: Cambridge University Press.

Chaucer, Geoffrey. 1984. Troilus and Criseyde: A New Edition of "The Book of Troilus”, ed. B.A. Windeatt. London: Longman.

Chaucer, Geoffrey. 1987. The Riverside Chaucer, ed. Larry D. Benson. Oxford: Oxford University Press.

Curry, Walter Clyde. 1960. Chaucer and the Mediaeval Sciences. New York: Barnes and Noble.

Damasio, Antonio. 2000. The Feeling of What Happens: Body, Emotion and the Making of Consciousness. London: Vintage.

Damasio, Antonio. 2006 [1994]. Descartes' Error: Emotion, Reason and the Human Brain. London: Vintage.

Getz, Faye. 1998. Medicine in the English Middle Ages. Princeton: Princeton University Press.

Gower, John. 1900, 1901. Confessio Amantis: The English Works of John Gower, vol. 2, ed. G.C. Macaulay. Early English Text Society, ES 81 and 82. London: Oxford University Press.

Grudzen, Gerald J. 2007. Medical Theory About the Body and the Soul in the Middle Ages: The First Western Medical Curriculum at Monte Cassino. Lewiston: Edwin Mellen Press.

Harvey, Ruth. 1975. The Inward Wits: Psychological Theory in the Middle Ages and the Renaissance. London: Warburg Institute, University of London.

Hilger, Stephanie M. (ed.). 2017. New Directions in Literature and Medicine Studies. London: Palgrave Macmillan.

Isidore of Seville. 2006. The Etymologies of Isidore of Seville, trans. Stephen A. Barney, W.J. Lewis, J.A. Beach, Oliver Berghof, with Muriel Hall. Cambridge: Cambridge University Press.

James, William. 1884. What Is an Emotion? Mind 9: 188-205.

James, William. 1912. What Is Consciousness? In Essays in Radical Empiricism, ed. Ralph Barton Perry, 1-38. New York: Longmans, Green.

Keats, John. 1970. The Poems of John Keats, ed. Miriam Allott. Longman Annotated English Poets. London: Longman.

Knuuttila, Simo. 2004. Emotions in Ancient and Medieval Philosophy. Oxford: Oxford University Press.

Metlitzki, Dorothee. 2005. The Matter of Araby in Medieval England. New Haven: Yale University Press.

Pickavé, Martin, and Lisa Shapiro (eds.). 2012. Emotion and Cognitive Life in Medieval and Early Modern Philosophy. Oxford: Oxford University Press. 
Porter, Roy. 1997. The Greatest Benefit to Mankind: A Medical History of Humanity from Antiquity to the Present. London: HarperCollins.

Rawcliffe, Carole. 1995. Medicine and Society in Later Medieval England. Stroud: Sutton.

Rolle, Richard. 1915. The "Incendium Amoris" of Richard Rolle of Hampole, ed. Margaret Deanesley. Manchester: Manchester University Press.

Rolle, Richard. 1972. The Fire of Love, trans. Clifton Wolters. Harmondsworth: Penguin.

Rubin, Stanley. 1974. Medieval English Medicine. New York: Barnes and Noble.

Saunders, Corinne. 2001. Rape and Ravishment in the Literature of Medieval England. Cambridge: D.S. Brewer.

Siraisi, Nancy G. 1990. Medieval and Early Renaissance Medicine: An Introduction to Knowledge and Practice. Chicago: University of Chicago Press.

Talbot, C.H. 1967. Medicine in Medieval England. London: Oldbourne.

van der Eijk, Philip J. 2005. Medicine and Philosophy in Classical Antiquity: Doctors and Philosophers on Nature, Soul, Health and Disease. Cambridge: Cambridge University Press.

Verbeke, G. 1945. L'Évolution de la doctrine du pneuma du stoïcisme à S. Augustin, étude philosophique. Bibliothèque de l'Institut Supérieur de Philosophie, Université de Louvain. Paris: Desclée de Brouwer.

Wack, Mary. 1990. Lovesickness in the Middle Ages: The Viaticum and Its Commentaries. Philadelphia: University of Pennsylvania Press.

Weiss, Judith. 2011. Modern and Medieval Views on Swooning: The Literary and Medical Contexts of Fainting in Romance. In Medieval Romance, Medieval Contexts, ed. Rhiannon Purdie and Michael Cichon, 121-134. Studies in Medieval Romance. Cambridge: D.S. Brewer.

Windeatt, Barry. 2011. The Art of Swooning in Middle English. In Medieval Latin and Middle English Literature: Essays in Honour of Jill Mann, ed. Christopher Cannon and Maura Nolan, 211-230. Cambridge: D.S. Brewer. 
Open Access This chapter is licensed under the terms of the Creative Commons Attribution 4.0 International License (http://creativecommons.org/licenses/ by $/ 4.0 /$ ), which permits use, sharing, adaptation, distribution and reproduction in any medium or format, as long as you give appropriate credit to the original author(s) and the source, provide a link to the Creative Commons license and indicate if changes were made.

The images or other third party material in this chapter are included in the chapter's Creative Commons license, unless indicated otherwise in a credit line to the material. If material is not included in the chapter's Creative Commons license and your intended use is not permitted by statutory regulation or exceeds the permitted use, you will need to obtain permission directly from the copyright holder.

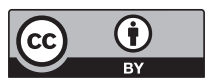

